MILAN RADOVANOVIĆ, PhD, historian

Belgrade, Republic of Serbia

mradowanovic@gmail.com

originalan naučni rad / original scientific paper

primljeno / received: 11. 2. 2020.

prihvaćeno / accepted: 20. 5. $2020 . \quad$ UDK 314.15(=411.16)(569.4)"1948/.."(093.2)

https://doi.org/10.29362/ist20veka.2020.2.rad.187-202

\title{
MIGRATION SPAWNING MIGRATION - ON CONTINUITY IN JEWISH EMIGRATION FROM YUGOSLAVIA TO PALESTINE/ISRAEL
}

\begin{abstract}
The Yugoslav participation in the Jewish emigration to Mandatory Palestine and, after 1948, to Israel, can be defined as a process consisting of six stages. When the migration is observed on the level of sociopolitical circumstances, the discontinuity between these stages is apparent. However, the same discontinuity is not to be found when the process is deconstructed down to and examined on the level of families and individuals involved in it. The aspiration of individuals to join members of their families already in Palestine, especially after the tragic losses suffered in the Holocaust, has persevered as one of the key motives driving emigration from Yugoslavia. This paper examines the way in which family ties continuously drove emigration to Mandatory Palestine/Israel and pulled its individual stages into an integral whole. It is primarily based on documents kept at the Archives of the Jewish Historical Museum in Belgrade.
\end{abstract}

KEYWORDS: Migration, Yugoslavia, Israel, Jews, Continuity

\section{Introduction}

Honoring the different legal traditions of Jewish emancipation within its territories, the Kingdom of Yugoslavia granted full equality to local Jews. ${ }^{1}$ Although the state was rebuilt on different ideological foundations after World War II, the socialist authorities in Yugoslavia had more or less the same attitude toward the Jewish community as a whole after $1945 .^{2}$ Probably the most significant aspect of the government's continuous benevolence was a consistently

\footnotetext{
${ }^{1}$ Милан Кољанин, Јевреји и антисемитизам у Краљевини Југославији 1918-1941 (Београд: Институт за савремену историју, 2008), 70-80.

2 See in detail: Mladenka Ivanković, Jevreji u Jugoslaviji (1944-1952), Kraj ili novi početak (Beograd: Institut za noviju istoriju Srbije, 2009), 272-281; Mladenka Ivanković, Brodovi nade. Alije jugoslovenskih Jevreja u Izrael (Beograd: Heraedu, 2017), 54-55.
} 
liberal migration policy. The Kingdom, as well as the later socialist state played a very significant role in the settlement of Jewish émigrés in Mandatory Palestine, after 1948, the sovereign state of Israel. Yugoslavia was simultaneously a source of emigration and an important transit area. Whenever possible, depending on contemporary foreign and domestic political goals as well as objective circumstances, refuges were taken in and enabled to continue their journey, while local Jews were supported if they wished to emigrate.

Yugoslav participation in Jewish migration to Mandatory Palestine and later to Israel can be described as consisting of six stages. Up until 1933 only individual Jews were leaving Yugoslavia in order to settle in Mandatory Palestine. This migration dynamic drastically changed when the national socialists came to power in Germany. Between 1933 and 1940, approximately 50,000 Jewish refugees arrived in Yugoslavia, a substantial number of whom proceeded to go to Palestine. ${ }^{3}$ Compared to the general scale of this migration, the number of Yugoslav Jews participating in it was minuscule.

During World War II, Palestine was one of the territories in which $\mathrm{Yu}$ goslav Jews, fleeing from the "Final Solution", attempted to find refuge. ${ }^{4}$ However, few of them succeeded. In total, no more than 1,700 Jews from Yugoslavia settled in Mandatory Palestine in the period between 1933 and $1945 .^{5}$

After the war had ended, Yugoslavia once again assumed the role of a transit area, used by former concentration camp inmates illegally ${ }^{6}$ migrating to Palestine. ${ }^{7}$ Local Jews were strictly forbidden from joining in this movement, as Yugoslav authorities did not want to further jeopardize diplomatic relations with Great Britain. ${ }^{8}$ The only way Yugoslav citizens could migrate to Mandatory Palestine was if they had previously acquired an immigration certificate issued

\footnotetext{
${ }^{3}$ For more information on this stage of migration, see: Milan Ristović, „Jugoslavija i jevrejske izbeglice 1938-1941“, Istorija 20. veka, br. 1, (1996), 21-43; Milan Ristović, „Turisti pod sumnjom (o jednom vidu politike Kraljevine Jugoslavije prema jevrejskim izbeglicama 19381941. godine)“, u: Kladovo transport: Zbornik radova sa okruglog stola, urednik Andrej Mitrović (Beograd: Jevrejski istorijski muzej, 2006), 170-189; Milan Ristović, „Unsere und fremde Juden. Zum Problem der Jüdischen Flüchtlinge in Jugoslawien 1938-1941“, in: Zwischen grossen Erwartungen und bösem Erwachen. Juden, Politik und Antisemitismus in Ostund Südosteuropa 1918-1945, Herausgegeben von Dittmar Dahlmann und Anke Hilbrenner (Paderborn - München: Schöningh, 2007), 191-216; Anna Grünfelder, „Aufgeschobene Vernichtung. Jüdische Emigration nach Jugoslawien (1933-1938-1945)“, Südosteuropaforschung, nr. 71, (2012), 233-284; Anna Maria Gruenfelder, „Nepoželjni gosti. Židovske izbeglice u Jugoslaviji (1938-1945)“, Zbornik Jevrejskog istorijskog muzeja, br. 10, (2015), 303-362.

${ }^{4}$ See: Милан Ристовић, У потрази за уточиштем - Југословенски Јевреји у бекству од Холокауста (Београд: Чигоја штампа, 2016).

${ }^{5}$ Melita Švob, Židovska populacija u Hrvatskoj i Zagrebu (Zagreb: Židovska općina Zagreb i Istraživački i dokumentacijski centar CENDO, 2010), 136.

${ }^{6}$ The process of illegal immigration to Mandatory Palestine is reffered to as Aliyah Beth, so as to differentiate it from simultaneous legal immigration, for which the designation is Aliyah Alef.

${ }^{7}$ See in detail: Mladenka Ivanković, „Odlazak jevrejskih izbeglica - žrtava Holokausta iz evropskih zemalja za Palestinu preko teritorije Jugoslavije 1946/7. godine“, Tokovi istorije, br. 3, (2006), 141-153 and M. Ivanković, Jevreji u Jugoslaviji (1944-1952)..., 305-307.

${ }^{8}$ M. Ivanković, Jevreji u Jugoslaviji (1944-1952).., 312-313; M. Ivanković, Brodovi nade..., 63-64.
} 
by the British authorities. ${ }^{9}$ Fifty such certificates were assigned to the local community every year and the Federation of Jewish Religious Communities of Yugoslavia was placed in charge of distributing them. ${ }^{10}$

When in May of 1948 the independent state of Israel was proclaimed, all existing limitations on immigration were dropped. Between 1948 and 1951 approximately 700,000 Jewish immigrants from all around the world found themselves in the newly established state. ${ }^{11}$ Over the same period five waves of organized emigration (with a total of 7,739 participants) left Yugoslavia for Israel. ${ }^{12}$ This organizational form was abandoned when the number of applicants no longer warranted a coordinated effort by local or international Jewish organizations with Yugoslav and Israeli authorities. After 1952, emigration from Yugoslavia resumed on an individual level. Beyond 1948, a relatively small number of refugees made their way across Yugoslav territory to Israel. There were, however, still foreign citizens taking part in the migration process. ${ }^{13}$

The nature of the role played by Yugoslavia in the immigration to Mandatory Palestine and later to Israel depended completely on the circumstances in the sphere of foreign and domestic policy. Borders between individual stages of the process therefore reflect key moments in the history of the Yugoslav state. Analyzing this migration movement on the level of state and the organizations participating does appropriately reflect its complexity, as it gives the appearance of a process defined by clear discontinuities. On the lower levels of participating in the process, we find clear causal links between the separate stages of migration.

$$
* * *
$$

This paper focuses on defining more precisely the continuity that exists between individual stages within the migration movement of Jews from Yugoslavia and across Yugoslav territory to Mandatory Palestine and, later, Israel. The interconnectedness and causality were examined by deconstructing and analyzing each of the individual stages on three separate but mutually interconnected hori-

\footnotetext{
${ }^{9}$ As of January 30th 1946, British authorities allowed the monthly immigration of 1,500 Jews. See: Richie Ovendale, Britain, the United States and the end of the Palestine mandate (19421948) (London: Royal Historical Society, 1989), 111-112.

${ }^{10}$ It should be pointed out that the first contingent of certificates never was used. On account of damaged roads in Yugoslavia, the certificates didn't make it to the applicants on time for them to leave the country. See: M. Ivanković, Jevreji u Jugoslaviji (1944-1952).., 307 and M. Ivanković, Brodovi nade..., 64-65.

${ }^{11}$ Itzhak Alfassi, Immigration and Settlement (Jerusalem; Ketter Books, 1973), 56 and Shoshanna Neumann, Aliyah to Israel: Immigration under Conditions of Adversity (Bonn: Forschungsinstitut zur Zukunft der Arbeit, 1999), 1-5.

12 Милан Радовановић, „Поједини статистички аспекти организованог исељавања Јевреја из Југославије у Израел (1948-1952)“, Годишъак за друштвену историју, бр. 2, (2015), 66.

${ }^{13}$ There are even cases recorded of individuals who arrived in Yugoslavia as refugees during the interwar period, only to join in the organized emigration after the war ended. See: Milan Radovanović, "Der Transit jüdischer Migranten durch Jugoslawien nach Palästina und Israel (1933-1952) - der Fall Ernest Beschinsky”, Istorija 20. veka, br. 1, (2016), 109-118.
} 
zontal levels of participation. ${ }^{14}$ The first of these levels consists of states and Jewish organizations taking part in the process. Collectives and groups belong to the second level of deconstruction, while individual émigrés make up the third. The (dis-)continuity between the individual stages of the migration movement is best seen in the point separating the second and third levels of deconstruction, while analyzing the participation of groups and individuals.

Individual families, a prime example of small and intimate groups, ${ }^{15}$ played a very significant role in the migration of Jews from and through Yugoslavia to Mandatory Palestine and, subsequently Israel. It was the community already in Palestine when the war ended that was the key factor driving future emigration from Yugoslavia. Having suffered huge losses in the Holocaust, ${ }^{16}$ a significant part of the émigrés was motivated to leave Yugoslavia by the wish to reunite with their surviving family members. ${ }^{17}$ This led to every stage of migration (albeit differing in character and volume) impacting on the ones to follow.

${ }^{14}$ More on the method applied: Milan Radovanović, ,The State, the Organization and the Individual - A three-level Approach to Migration", In: Where is Civil Society in Central Europe heading to?, Edited by Inocent-Mária Staniszlo et al (Prešov: Michal Vaško Press, 2015), 169-187, and Милан Радовановић, „Исељавање Јевреја из Југославије у Израел (1948-1952)“ (докторска дисертација, Универзитет у Београду, Филозофски факултет, Одељење за историју, 2015) 6-11.

${ }^{15}$ Depending on the specific method applied as well as their unique focus, different social sciences work with different definitions of a group. Sociology defines a group as the basic entity within a functioning society, consisting of a number of individuals connected by one or more common causes. The measure of an individual ignoring his own goals so as to help the realization of a group cause or an individual prioritizing group causes to his own is called the level of group cohesion. As the group grows, the level of cohesion goes down. Accordingly, small groups are the most stable. See: Judy Gahagan, Interpersonal and Group Behaviour (London: Methuen, 1975), 66-67. All the characteristics of a group and its function are defined by the term entitativity. Based on entitativity, groups are categorized as loose gatherings, social categories, work groups and, finally, intimate groups. See: Richard Crisp and Rhiannon Turner, Essential Social Psychology (London: Sage, 2007), 17. Psychology somewhat narrows down the definition used by sociology, considering a group to be a number of individuals connected by at least one mutual characteristic or similar interest. It differentiates between groups in the narrower sense (structured groups) and groups in the broader sense (unstructured groups). There are three kinds of structured groups - organizations, large groups and small groups. Apart from the characteristics common to structured groups (common goal, interaction, structure, group norms and an individual's consciousness about belonging to a group), small groups are defined by a limited number of members, their direct interaction and co-dependence, as well as the existence of mutual influence. See: Никола Рот, Психологија група. Изабрана дела - том IV (Београд: Завод за издавање уџбеника, 2010), 52-53.

${ }^{16}$ Losses suffered by the Jewish community in Yugoslavia during the Holocaust are usually cited as being around $80 \%$ of the population. See: Albert Vajs, „Jevreji u novoj Jugoslaviji“, Jevrejski almanah, (1954), 24; Драган Цветковић, „Холокауст у Југославији - један покушај квантификације: методологија, питања, проблеми, резултати“, у: Израелско-српска научна размена у проучавағу Холокауста, Зборник радова с научног скупа (Јерусалим Jaд Вашем, 15 - 20. јун 2006) (Београд: Музеј жртава геноцида, 2009), 346; Jaša Romano, Jevreji Jugoslavije 1941-1945. Žrtve genocida i učesnici Narodnooslobodilačkog rata (Beograd: Savez jevrejskih opština Jugoslavije, 1980), 202.

17 See: Милан Радовановић, „Ционизам и прагматизам - Зашто су се југословенски Јевреји иселили у Израел? (1948-1952)“, Београдски историјски гласник, бр. 6, (2015), 235-236. 


\section{Individual Emigration (1945-1948)}

The need for securing an immigration certificate meant that the Yugoslav community in Palestine was not just one of the chief forces driving emigration in the first few post-war years, but also an integral part of the process itself. Addressing the subject of emigration in April of 1946, the members of the Executive Committee of the Federation of Jewish Religious Communities of Yugoslavia characterized the interest shown by locals who had relatives living in Mandatory Palestine in leaving the country as being "acute."18 The distribution of immigration certificates proceeded in accordance with this conclusion. After distributing the personalized certificates,${ }^{19}$ the members of the Executive Committee prioritized the following categories of applicants ${ }^{20}$

1. Parents with children in Palestine

2. Children with parents in Palestine

3. Widows with parents or siblings in Palestine

4. Unmarried women with parents or siblings in Palestine.

The members of the local community expressing interest in leaving Yugoslavia seized on opportunities created by this Executive Committee decision and regularly listed relatives in Palestine who were awaiting their arrival when applying for emigration in the first few post-war years.

By giving preference to individuals with relatives already living there, the Federation executives formalized the role played by the Yugoslav community in Mandatory Palestine in the emigration between 1945 and 1948. Individuals applying to leave the country were further advised to acquire one of the few immigration certificates through their family members already abroad. ${ }^{21}$ In this

Although part of the same process, the emigration of parentless children who left Yugoslavia honnoring the wishes of their relatives abroad will not be concidered in this paper. On this subject, see: Милан Радовановић, „Исељење јеврејске деце из Југославије у Израел 1948/9“, Наша прошлост, бр. 14, (2013), 161-170. and Милан Радовановић, „Емиграција јеврејске деце из Југославије у Израел (1948-1952) - Три личне историје“, Токови историје, бр. 2, (2017), 155-174.

${ }^{18}$ See: Archives of the Jewish Historical Museum (AJHM), provisional box (p.b.) 781, Zapisnik sa VIII sednice Izvršnog odbora (IO) Saveza jevrejskih veroispovednih opština Jugoslavije (SJVOJ), April $21^{\text {st }} 1946$.

${ }^{19}$ AJHM, p.b. 781, Zapisnik sa VIII sednice IO SJVOJ, April $21^{\text {st }} 1946$.

${ }^{20}$ See: AJHM, p.b. 781, Zapisnik sa X sednice IO SJVOJ, May $25^{\text {th }} 1946$. Although the selection of émigrés was as a rule left up to the Federation, Jewish agency executives advised them to give the advantage to relatives of military members, AJHM, Aliyah (Al.) 1950-1951, p.b. 801 (Perera Archive 40), Prevod (Dopis Jevrejske agencije), April 10 ${ }^{\text {th }} 1946$, pov. br. 462/46. The same documents suggest that "relatives" were assigned a certain number of the 50 certificates granted to the Yugoslav community on a yearly basis, but it remains unclear what this comment specifically refers to.

${ }^{21}$ See: AJHM, Aliyah (Al.) 1950-1951, p.b. 801 (Perera Archive 40), Dopis SJVOJ - Viktoru Rajhu, April $10^{\text {th }} 1946$. As this is the only document suggesting that Yugoslav Jews living in Israel played a role in securing certificates for further immigration, many aspects of their activity in this respect remain unclear. 
way Yugoslav Jews living in Palestine were openly engaged in enabling the further development of the migration process. $^{22}$

His two sisters, who had been living in Palestine for years, invited Slavko Vajs from Kutina to join them in July of $1946 .{ }^{23}$ They promised to take care of all the formalities and send him a certificate via the Federation. The case of Ignjat Grin from Bač was very similar. ${ }^{24}$ He asked the Federation executives to help him prepare the documents needed to conclude the emigration process by mediating with the Yugoslav authorities. ${ }^{25}$ His two sons, living in Palestine had already secured an immigration certificate for him.

In mid-1946, Mirjam Kosi approached the Federation executives, asking them to keep her in mind for emigration. ${ }^{26}$ She was waiting for her son, who had left for Palestine during the war and settled in the Kibbutz Sha'ar HaAmakim, ${ }^{27}$ to secure immigration certificates for her and her granddaughter. ${ }^{28}$

After having lost his mother and his little brother in the Holocaust, Viktor Reich was left with no family in Yugoslavia. ${ }^{29}$ Shortly after the war had ended he decided to emigrate together with his wife and join his brother who had been living in Mandatory Palestine since 1928. He asked the Federation executives to help him get an immigration certificate or at least give him detailed instructions on how to acquire one.

Herman and Berta Domanji from Tuzla addressed the Federation in early April of 1946, asking for help with the emigration process. ${ }^{30}$ Their two sons and one daughter had settled in Palestine ${ }^{31}$ and worked toward securing the

${ }^{22}$ The key role played by the Yugoslav community in Mandatory Palestine in emigration over the first post-war years was recognized by the Jewish Agency as well. In a letter addressed to the Federation in April of 1946, Agency executives state that up to that point, the relatives of 45 people applying for immigration had reached out to them. See. AJHM, Al. 1950-1951, p.b. 801 (Perera Archive 40), Prevod (Dopis Jevrejske agencije), April 10 $0^{\text {th }} 1946$, pov. br. 462/46. This kind of administrative solution caused, among other things, an unusually large number of documented cases of individuals pointing out that they were leaving Yugoslavia after the war motivated by the desire to join their relatives living in Palestine.

${ }^{23}$ AJHM, Al. 1950-1951, p.b. 801 (Perera Archive 40), Pismo Slavka Vajsa - SJVOJ-u, August $22^{\text {nd }} 1946$.

${ }^{24}$ AJHM, Al. 1950-1951, p.b. 801 (Perera Archive 40), Pismo Ignjata Grina iz Bača - Fridrihu Popsu, December 22 $2^{\text {nd }} 1946$, pov. br. 776/46.

${ }^{25}$ It seems that in this case, the certificates never even made it to the Federation. See: AJHM, Al. 1950-1951, p.b. 801 (Perera Archive), Dopis SJVOJ - Grin Ignjatu iz Bača, January $3^{\text {rd }} 1947$, pov. br. $776 / 46$.

${ }^{26}$ AJHM, Al. 1950-1951, p.b. 801 (Perera Archive 40), Dopis Mirjam Kosi - SVJOJ-u, July $15^{\text {th }} 1946$.

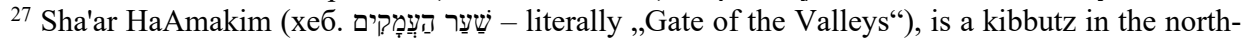
ern part of Israel. It was founded in 1935 by Jews emigrating from Yugoslavia and Romania.

${ }^{28}$ AJHM, Al. 1950-1951, p.b. 801 (Perera Archive 40), Dopis Mirjam Kosi - SVJOJ-u, July $15^{\text {th }} 1946$.

${ }^{29}$ AJHM, Al. 1950-1951, p.b. 801 (Perera Archive 40), Pismo Viktora Rajha - SJVOJ-u, April $7^{\text {th }} 1946$, pov. br. $211 / 46$.

30 AJHM, Al. 1950-1951, p.b. 801 (Perera Archive 40), Dopis Hermana i Berte Domanji SJVOJ-u, April 1 $1^{\text {st }}$ 1946, pov. br. 207/46.

${ }^{31}$ A list of Yugoslav citizens living in Palestine kept by the consulate in Jerusalem names Dezider Domanji, from Petah Tikva (Arhiv Jugoslavije/Archive of Yugoslavia (AJ), Generalni konzulat Kraljevine Jugoslavije u Jerusalimu/General Consulate of the Kingdom of Yugoslavia in Jeru- 
immigration of their parents. After losing their third son in the war, ${ }^{32}$ Herman and Berta Domanji were left all alone in Yugoslavia. ${ }^{33}$ Already seniors, they were completely dependent on their children and on joining them in Palestine. Although the certificates earmarked for Berta and Herman Domanji took much longer to arrive in Yugoslavia than originally expected, in the end they succeeded in leaving the country. ${ }^{34}$

The individual emigration of the first post-war years demonstrated a clear wish by members of the Jewish community in Yugoslavia, especially those left alone after the Holocaust, to renew family life with relatives living in Palestine. However, the number of certificates made available to the Federation of Jewish Religious Communities severely limited the scale of this stage of the migration process. Only organized emigration presented the proper opportunity for all the interested members of the Jewish community to leave Yugoslavia.

\section{Organized Emigration (1948-1952)}

With restrictions on immigration lifted in May of 1948, the Yugoslav community in Israel, which was constantly growing in numbers during the interwar period and the first post-war years, turned into one of the chief agents of further emigration. ${ }^{35}$ When considering the impact of previous stages of migra-

salem (430), fascikla 5, arhivska jedinica 20, Spisak naših državljana u Palestini) and Alfred Domanji (AJ, 430-3-16, Spisak lica jugoslovenskog porekla primljenih u palestinsko državljanstvo (1938-1941)). Documents at hand don't contain any more details about the persons named, but since they are the only émigrés from Yugoslavia with the same surname, one can assume they are the sons of Herman and Berta Domanji. The two also pointed out that one of their sons had moved to Palestine during the war, which is consistent with the data of the Consulate, AJHM, Al. 1950-1951, p.b. 801 (Perera Archive 40), Dopis Hermana i Berte Domanji - SJVOJ-u, April $1^{\text {st }} 1946$, pov. br. 207/46.

32 Domanji Emil-Cigo joined the National liberation Army (NOB) in September of 1943. As a fighter with the VI division from Lika, he was killed in 1944 during the operation "Knights Move". See: J. Romano, Jevreji Jugoslavije 1941-1945 ..., 354.

33 AJHM, Al. 1950-1951, p.b. 801 (Perera Archive 40), Dopis Hermana i Berte Domanji SJVOJ-u, April $1^{\text {st }}$ 1946, pov. br. 207/46.

${ }^{34}$ What occurred was a big misunderstanding between the Jewish Agency, the Federation of Jewish religious communities of Yugoslavia and the future émigrés. Through the British Embassy in Belgrade, Federation executives were informed that the certificates were sent directly to the Domanji family instead of to the Federation. Concerning this problem, the Domanji family addressed the Jewish Agency. How the certificates ended up with Herman and Berta Domanji remains unclear. See: AJHM, Al. 1950-1951, p.b. 801 (Perera Archive 40), Dopis Hermana Domanjija - SJVOJ-u, May 29 ${ }^{\text {th }}$ 1946; AJHM, Al. 1950-1951, p.b. 801 (Perera Archive 40), Pismo Hermana Domanjija - SJVOJ-u, August $8^{\text {th }} 1946$, pov. br. 536/46. and AJHM, Al. 1950-1951, p.b. 801 (Perera Archive 40), Dopis Hermana Domanjija - SJVOJ-u, August $12^{\text {th }}$ 1946, pov. br. 537/46; AJHM, Al. 1950-1951, p.b. 801 (Perera Archive 40), Dopis SJVOJ Hermanu Domanjiju iz Tuzle, August $16^{\text {th }} 1946$.

35 There are 463 applications for organized emigration kept in AJIM, Al. 1948, p.b. 774, and AJIM, Al. 1948, p.b. 907. Approximately one quarter of these applicants state that there were relatives waiting for them in Israel. While it certainly can not be considered as representing the migration process as a whole, it is indicative of the general significance of the role played by family in it. Compared to the individual migration of the post-war years, relatively few émigrés 
tion on the current one, organized emigration is a particularly complex phenomenon. Mass emigration between 1948 and 1952 was primarily influenced by the settlement of Yugoslav Jews in Mandatory Palestine during the interwar period and the first postwar years. However, every new individual wave of organized migration was in part also made possible by the previous one(s). Considering the number of participants alone, the first wave of organized emigration from Yugoslavia to Israel was particularly important in this regard. ${ }^{36}$

In late October of 1948, Herta Wertheimer-Krneta reached out to the Yugoslav Ministry of Internal Affairs. ${ }^{37}$ Her brother Willy, who held a "highranking position" in the Kibbutz Givath Haim, ${ }^{38}$ attempted to bring her to Palestine as soon as the war had ended. ${ }^{39}$ For reasons unknown, she first applied to leave the country when organized emigration started. She addressed the Ministry because she was surprised that her own application had been accepted, while that of her husband Fedor Krneta had not. She pointed out that the reason she had decided to migrate to Israel was to see her brother again, as he was the only member of her family to survive the Holocaust.

At the insistence of the Federation executives, the Jewish religious community of Zagreb submitted a report about family members awaiting the arrival of three of their members who had applied earlier for organized emigration to Israel. ${ }^{40}$ Mira Pik and Valerija Kovačević, née Pik, pointed out that they had cousins waiting for them in the newly independent Jewish state - Nada Tirc in Kfar Saba, ${ }^{41}$ Hermina Štajner in Haifa, Irena Zisler and Sili Mantel in Tel Aviv. ${ }^{42}$ They also mentioned that the only relatives they had left in Yugoslavia were their uncle Isa Pik and their aunt Lili Hermanski, both of whom were too old to leave the country.

stated that their chief motivation for leaving Yugoslavia was joining their family members in Israel. This fact is most likely influenced by changes made in administrative procedure. Free immigration meant that relatives living in Israel no longer played an active role in the process. The relatively small number of documents in which the Yugoslav community in Israel is directly named as a factor in migration does not however mean that family members were less important in an individual reaching a decision to leave the country.

${ }^{36}$ In late 1948, a little over 4 thousand members of the Jewish community (or one third of the World War Two survivers) left Yugoslavia. See: М. Радовановић, „Поједини статистички аспекти...“, 64-66.

${ }^{37}$ AJHM, Al. 1948-1949, p.b. 897, Pismo Herte Verthajmer - MUP FNRJ, October 30 1948.

38 Givat Haim (heb. גבעת חיים - literally, the Hill of Haim) is a former kibbutz near Hadera, founded in 1932 by European immigrants. After a split between MAPAI and MAPAM supporters, the original kibbutz split into two separate settlements in 1952 - Givat Haim (Ihud) and Givat Haim (Meuhad)

${ }^{39}$ AJHM, Al. 1948-1949, p.b. 897, Pismo Herte Verthajmer - MUP FNRJ, October 30 1948.

${ }^{40}$ AJHM, Al. 1948, p.b. 856, Dopis JVO Zagreb - SJVOJ-u, October $16^{\text {th }} 1948$.

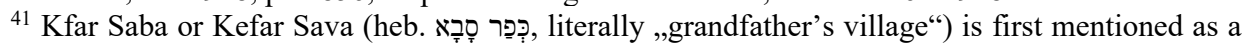
center of commerce during the Period of the Second Temple (586 B.C. - 70 B.C.). Under Roman and Byzantine rule it lost its significance, only to be reestablished as a Jewish settlement in 1898, during the Ottoman Empire. It was almost destroyed during World War One. As a kibbutz, it was reestablished in the twenties and finally got city status in 1962 .

${ }^{42}$ AJHM, Al. 1948, p.b. 856, Dopis JVO Zagreb - SJVOJ-u, October $16^{\text {th }} 1948$. 
By mid 1949, causation by previous stages of migration gave way to causation by previous waves of organized migration. During preparations for the first wave of organized emigration, Arnošt Koudelka, a Czechoslovakian citizen living in Belgrade, expressed the wish to join his relatives living in Palestine. ${ }^{43}$ His wife Natalija and daughter Silvija, both Yugoslav citizens, had emigrated in the previous wave of organized emigration. As Koudelka was a Czechoslovakian citizen, however, after he had acquired permission from the Czechoslovakian embassy in Belgrade, he had to wait for the same kind of permission from the Czechoslovakian Embassy in Israel. ${ }^{44} \mathrm{He}$ was unable to acquire all the documents needed in time to leave the country with his family. ${ }^{45}$ Although it is possible that he had left the country individually in the meantime, Arnošt Koudelka was not part of any of the organized emigration waves to follow. ${ }^{46}$

While preparations for the second wave of organized migration were underway, an anonymous letter reached the Federation of Jewish Religious Communities of Yugoslavia. ${ }^{47}$ An unnamed individual elaborated on what had motivated him to apply to leave the country. His late wife's aunt, who had been living in Jaffa for the better part of thirty years, invited him to join her. During the war, his younger brother had fled to Palestine too.

Isak Papić, a lieutenant with the Yugoslav Air Force from Pula ${ }^{48}$ wrote a letter to the Federation barely a month after the first wave of organized emigration had been completed. ${ }^{49} \mathrm{He}$ did not even apply for emigration in late 1948 , as none of the relevant information had reached him in time. Pointing out that he wanted to join his sister, who had been living in Palestine since 1943, Papić asked the Federation executives to keep him informed about the general

${ }^{43}$ AJHM, Al. 1948-1951, p.b. 768, Dopis Arnošta Koudelke - Predstavništvu države Izrael u Pragu, December 10th. 1948.

${ }^{44}$ Foreign citizens were as a rule allowed by Yugoslav authorities to join in the organized emigration to Israel, provided they have a valid passport and a visa from their country of origin. See: AJHM, Al. 1950, p.b. 755, Dopis SJVOJ - svim jevrejskim veroispovednim opštinama Jugoslavije, Predmet: Odlazak u državu Izrael, August $26^{\text {th }} 1948$, pov. br. 1216/48; AJHM, Al.1948, p.b. 827, Dopis SJVOJ - svim jevrejskim veroispovednim opštinama Jugoslavije, Predmet: Drugo iseljenje u državu Izrael, February $19^{\text {th }} 1949$, pov. br. 342/49; AJHM, A1. 1949, p.b. 1288, Dopis SJVOJ - svim jevrejskim veroispovednim opštinama Jugoslavije (Cirkular br. I), Predmet: Treće iseljenje u državu Izrael, October $23^{\text {rd }} 1949$, pov. br. 3481/49; AJHM, Al. 1948, p.b. 827, Dopis svim jevrejskim veroispovednim opštinama Jugoslavije (Cirkular br. I), Predmet: Četvrto grupno iseljenje u državu Izrael; AJHM, Al. 1948, p.b. 855, Dopis SJVOJ - svim jevrejskim veroispovednim opštinama Jugoslavije (Cirkular br. I), Predmet: Peto grupno iseljenje u državu Izrael, April $12^{\text {th }} 1952$, pov. br. 604/52.

${ }^{45}$ AJHM, p.b. 738, Spisak iseljenika za Izrael, XII 1948 - I 1949.

${ }^{46}$ AJHM, p.b. 738, Spisak iseljenika za Izrael, XII 1948 - I 1949; AJHM, Al. 1949, p.b. 1288, Spisak iseljenika (II Alija); AJHM, Al. 1949, p.b. 1288, Spisak iseljenika (III alija); AJHM, Al. 1949, p.b. 1288, Spisak (IV alija); AJHM, Al. 1951-1952, p.b. 801 (Perera Archive 40), Spisak prijavljenih lica za peto grupno iseljenje, juli 1952.

${ }^{47}$ AJHM, Al. 1948, p.b. 797, Motivacija k molbi za repatrijaciju u Izrael, April $3^{\text {rd }} 1949$.

48 AJHM, Al. 1948, p.b. 757, Dopis SJVOJ - Isaku Papiću, vazduhoplovnom poručniku, Pula, March $9^{\text {th }} 1949$, pov. br. $419 / 49$.

${ }^{49}$ AJHM, Al. 1948, p.b. 757, Pismo Isaka Papića - SJVOJ-u. 
conditions under which he would be able to leave the country and if army officers would even be allowed to participate in the migration. ${ }^{50} \mathrm{He}$ added that none of his relatives in Yugoslavia had survived the war. ${ }^{51}$ Together with the first circular letter concerning the second wave of organized emigration, Papić received instructions to contact the community of Rijeka for any further information on the process. ${ }^{52}$

At the end of February 1949, Jelka Jung of Osijek asked the Federation if she could use the permission received to visit her daughter in Israel and leave Yugoslavia for good. ${ }^{53}$ A similar wish was expressed by Viktor Taub, a veterinarian from Lovćenac, who asked the Federation executives to allow him and his wife to join their daughter, who had moved to Israel earlier. ${ }^{54}$

The formal initiative for leaving the country as part of the organized emigration movement shifted completely from the Yugoslav community in Israel to the Jewish community in Yugoslavia. However, there were still examples of Yugoslav Jews in Israel who were actively insisting the Federation help their relatives leave the country. As part of the second wave of organized migration, in March of 1949, Doctor Alador Mencer of Ber Jakob ${ }^{55}$ applied to the Federation. ${ }^{56}$ He left the country at the end of the previous year, without having left any close relatives in Yugoslavia. However, as soon as he had arrived in Israel, he felt the need to bring over the widow and daughter of a relative of his who had died in the war. Claiming he was lonely in Israel, he asked the Federation executives to help along the emigration of Irina and Edita Mencer from Vršac. They left the country in mid-1949. ${ }^{57}$

After the third wave of mass emigration had been completed, the executives of the community of Osijek addressed the Federation concerning the wish of a member, Dita Kovač, to join her son who had left for Israel in late $1948 .^{58}$ As she had missed the opportunity to apply, she was inquiring if she could leave

${ }^{50}$ Towards the position of military personnel within the organized emigration movement, see: M. Радовановић, Исељаваъе Јевреја из Југославије (1948-1952)..., 380-391.

${ }^{51}$ AJHM, Al. 1948, p.b.. 757, Pismo Isaka Papića - SJVOJ-u.

52 AJHM, Al. 1948, p.b. 757, Dopis SJVOJ - Isaku Papiću, vazduhoplovnom poručniku, Pula, March $9^{\text {th }} 1949$, pov. br. $419 / 49$.

${ }^{53}$ She even suggested leaving for Israel with one of the ships delivering the first wave of émigrés luggage with a delay. See: AJHM, Al. 1948, p.b. 757, Dopis JVO Osijek - SJVOJ-u, February $29^{\text {th }} 1949$, pov. br. $53 / 49$.

${ }^{54}$ AJHM, Al. 1948, p.b. 757, Zasebna izjava kao prilog upitniku i stavljena u svrhu iseljenja u državu Izrael, April $5^{\text {th }} 1949$.

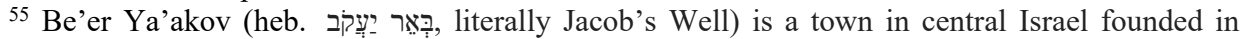
1907. Historically, it was divided into two sectors - one for the settlement of immigrants primarily coming from Russia, Poland, Romania, Bulgaria, Argentina and Iran and the other for Mountain (Caucasus) Jews. It was named after Ya'akov Yitzhaki, a rabbi and leader of the Mountain Jewish Community who had settled there.

${ }^{56}$ AJHM, Al. 1948, p.b. 797, Dopis dr Aladara Mencera iz Ber Jakoba, Bet Olima - SJVOJ-u, March $2^{\text {nd }} 1949$, pov. br. 386/49.

${ }^{57}$ AJHM, Al. 1949, p.b. 1288, Spisak iseljenika (II alija).

${ }^{58}$ AJHM, Al. 1948, p.b. 827, Dopis JVO Osijek - SJVOJ-u, Predmet: Individualno iseljenje Dite Kovač, u državu Izrael, May $4^{\text {th }} 1950$, pov. br. $1350 / 50$. 
for Israel individually or, if not, with the next wave of organized migration. The name Dita Kovač does not appear among the participants of the fourth wave of mass migration, ${ }^{59}$ but the possibility of her leaving the country at an earlier time cannot be excluded.

The interconnection between individual waves of organized emigration from Yugoslavia to Israel is perhaps seen most clearly in the case of Marija Radčenko. ${ }^{60}$ She informed the Federation executives that she was planning to leave Yugoslavia in 1951. She wanted to join her daughter Tatjana ${ }^{61}$ who was part of the third wave of migrations, following the emigration of her fiancé Vladimir, who arrived in Israel in mid-1949. Marija Radčenko applied for a certificate saying that her daughter, her son-in-law, and her grandchildren were waiting for her in Israel, so she could get a migration permit, as she was a Soviet citizen. ${ }^{62}$

Sofija Petrović Anaf addressed the Jewish religious community in Belgrade within preparations for the fifth wave of organized emigration. ${ }^{63} \mathrm{Her}$ daughter had migrated to Israel earlier and Petrović was asking the local community for financial aid so that she could join her. ${ }^{64}$

\section{Individual Emigration (1952-1963)}

The process of organized emigration from Yugoslavia to Israel ended after the fifth wave of migrants had left the country in October of $1952 .{ }^{65}$ The individual migration that ensued, although in varying numbers, continued up until the moment

${ }^{59}$ AJHM, Al. 1951-1952, p.b. 801 (Perera Archive 40), Četvrto grupno iseljenje u državu Izrael, maja 1951.

${ }^{60}$ AJHM, Al. 1950-1952, p.b. 756, Dopis Marije Radčenko - SJVOJ-u, Decembar $4^{\text {th }} 1950$, pov. br. $2367 / 50$.

${ }^{61}$ AJHM, Al. 1949, p.b. 1288, Spisak iseljenika (III Alija).

${ }^{62}$ AJHM, Al. 1950-1952, p.b. 756, Dopis SJVOJ - Mariji Radčenko iz Zagreba, December 6th 1950 , pov. br. $2367 / 50$.

${ }^{63}$ AJHM, Al. 1953, p.b. 754, Dopis Sofije Petrović Anaf - JVO Beograd, September $18^{\text {th }} 1952$.

${ }^{64}$ More on financial aid within the organized emigration movement see: Милан Радовановић, „Поједини економски аспекти организованог исељавања југословенских Јевреја у Израел 1948/9. године“, Годишґак за друштвену историју, бр. 3, (2011), 87-92. and Милан Радовановић, „Организована емиграција капитала - „Збирни рачун репатрираца за Израел“" (1948-1952)“, Архив, бр. 1-2, (2017), 166-171.

${ }^{65}$ Every wave of organized migration was assumed to be the last one. However, whenever the number of people interested was large enough for the Federation officials and state authorities to consider organized migration justified, another wave of emigration ensued. The organizational frame was almost identical to what had preceeded the previous wave. See: AJHM, Al. 1950, p.b. 755, Dopis SJVOJ - svim jevrejskim veroispovednim opštinama Jugoslavije, Predmet: Odlazak u državu Izrael, August 26 ${ }^{\text {th }} 1948$, pov. br. 1216/48; AJHM, Al.1948, p.b. 827, Dopis SJVOJ - svim jevrejskim veroispovednim opštinama Jugoslavije, Predmet: Drugo iseljenje u državu Izrael, February $19^{\text {th }} 1949$, pov. br. 342/49; AJHM, Al. 1949, p.b. 1288, Dopis SJVOJ - svim jevrejskim veroispovednim opštinama Jugoslavije (Cirkular br. I), Predmet: Treće iseljenje u državu Izrael, October $23^{\text {rd }} 1949$, pov. br. 3481/49; AJHM, Al. 1948, p.b. 827, Dopis svim jevrejskim veroispovednim opštinama Jugoslavije (Cirkular br. I), Predmet: Četvrto grupno iseljenje u državu Izrael; AJHM, Al. 1948, p.b. 855, Dopis SJVOJ - svim jevrejskim veroispovednim opštinama Jugoslavije (Cirkular br. I), Predmet: Peto grupno iseljenje u državu Izrael, April 12 $2^{\text {th }} 1952$, pov. br. 604/52. 
the Yugoslav state dissolved. The full frame of this migration stage could not be analyzed. However, the continuity between the post-1952 individual emigration and the previous stages is obvious even from the relatively few examples considered.

The post-1952 individual emigration was in form very similar to what migrations between 1945 and 1948. Acquiring a certificate was no longer a condition for immigration, but the Yugoslav community in Israel still played an active role in the process. Through the Hitachdut Olei Yugoslavia and the Federation of Jewish Communities, Yugoslav Jews in Israel attempted to help their family members emigrate. ${ }^{66}$

In early September of 1953, a letter from Samuel Kaveson from the Kibbutz $\mathrm{Gat}^{67}$ reached the Federation of Jewish religious communities. ${ }^{68}$ As his older brother Moric Kaveson from Drvar and his aunt, Sarina Altarac, from Travnik were preparing to leave the country, he asked the Federation executives to help them in their endeavor. ${ }^{69}$

In late 1953, Bencion Levi was addressed by Doctor Moses Levi ${ }^{70}$ of Ramat Gan, ${ }^{71}$ asking him for help with the emigration of his niece Vera Beck. ${ }^{72}$ She had applied for migration in 1950, but decided to pass up the opportunity to leave the country, as she wanted to get her degree in geology from the University of Belgrade. ${ }^{73}$ After doing so, she was left without the funds needed to finance her migration to Israel. ${ }^{74}$ The Federation executives took it upon themselves to help her reach Israel in every way provided she could collect all the documents demanded by the Yugoslav and Israeli authorities. ${ }^{75}$ The Jewish Agency offered to cover all costs arising from the migration process until the moment of boarding the ship bound for to Israel. ${ }^{76}$ Vera's sister Ana Beck left Yugoslavia in 1955 under very similar circumstances. ${ }^{77}$

${ }^{66}$ Within this stage, there was active communication between individuals applying for migration and Federation executives very similar to informal communication within the organized emigration process. See: Milan Radovanović, „The internal Framework of Organized Jewish Migration from Yugoslavia to Israel (1948-1952)", Istorija 20. veka, br. 1, (2019), 130-135.

${ }^{67}$ Gat (heb. תæ) is a kibbutz in southern Israel, founded in 1934. by immigrants from Poland, Yugoslavia and Austria.

${ }^{68}$ AJHM, p.b. 738, Dopis Hitahdut Olej Jugoslavije - SJVOJ-u, September $7^{\text {th }} 1953$, pov. br. $1640 / 53$.

${ }^{69}$ AJHM, p.b. 738, Dopis Hitahdut Olej Jugoslavije - SJVOJ-u, November $11^{\text {th }} 1953$.

${ }^{70}$ AJHM, p.b. 738, Dopis Hitahdut Olej Jugoslavije - SJVOJ-u, pov. br. 1782/53.

${ }^{71}$ Ramat Gan (heb. רֵַָת Tel-Aviv. Initially, the settlement was a Zionist agricultural colony (moshava). It was recognized as a city in 1950 .

${ }^{72}$ AJHM, p.b. 738, Dopis Jevrejske agencije u Jerusalimu - Albertu Vajsu, December $31^{\text {st }} 1953$ pov. br. $38 / 54$.

${ }^{73}$ AJHM, p.b. 738, Dopis SJVOJ - Jevrejskoj agenciji u Jerusalimu, Predmet: Vera Bek, inž. geodeta.

74 AJHM, p.b. 738, Dopis SJVOJ - Veri Vek iz Beograda, October 21 ${ }^{\text {st }} 1953$, pov. br. 1782/53.

75 AJHM, p.b. 738, Dopis SJVOJ - Mozesu Leviju iz Ramat Gana, February $11^{\text {th }} 1954$, pov. br. $222 / 54$.

${ }^{76}$ AJHM, p.b. 738, Dopis Jevrejske agencije u Jerusalimu - Albertu Vajsu, December $31^{\text {st }} 1953$ pov. br. 38/54. The Jewish agency was to give Vera Beck a special kind of stipend, which she 
In mid-1955, Branislava Marjanović from Belgrade decided to join her family, who had left for Israel with the first wave of organized emigration. ${ }^{78}$ The tipping point in reaching this decision was her daughter, who had left the country in 1954, insisting on it. ${ }^{79}$ As she wasn't able to finance the migration herself, she approached the Federation asking for aid. ${ }^{80}$ Petar and Irena Bence from Bačka Topola were left in a similar situation after organized emigration was done. ${ }^{81}$ Their son Petar and their daughter Rozalija Vajs, who had left the country earlier, insisted on bringing their parents to Israel.

Dov Jovanić called for his cousin Janko Grin and his family to join him in Israel in early July of 1955 . $^{82}$ Jovanić guaranteed he would take his cousins in and meet their material needs during their first few months of living in the newly founded Jewish state. After his aunt and his nephews had emigrated earlier, Branko Poljak from Zagreb decided to move to Israel himself in early $1954 .^{83}$ After having discussed it with his cousins, he applied to the Federation, asking for help in clearing up the administrative procedure preceding individual emigration.

\section{Conclusion}

When examined on the state level and the organizational level, the participation of the Yugoslav state in the Jewish emigration to Mandatory Palestine and after 1948 to Israel, seems like a process consisting of six clearly separate stages. The perception of the same process, however, shifts when it is analyzed on the level of the families and individuals taking part in it. Any individuals wishing to join their family members, who had left the country earlier, transcended the differences in character and number of participants between the different stages of the migration process, giving it an essentially integral character. This was especially true in light of the tragic losses suffered by the Jewish community in Yugoslavia during the Holocaust.

would have to repay from her future income in Israel. AJHM, p.b. 738, Dopis Jevrejske agencije - SJVOJ-u.

77 AJHM, p.b. 738, Dopis JVO Beograd - SJVOJ-u, Mai $13^{\text {th }} 1955$.

${ }^{78}$ AJHM, p.b. 738, Dopis JVO Beograd - SJVOJ-u, June $3^{\text {rd }} 1955$.

${ }^{79}$ As she stated in a request addressed to Federation executives, Marjanović hoped that they would "understand the wish of a mother to be reunited with her child". See: AJHM, p.b. 738, Dopis Branislave Marjanović - SJVOJ-u, May $25^{\text {th }} 1955$.

${ }^{80}$ AJHM, p.b. 738, Dopis SJVOJ - JVO Beograd, Mai $27^{\text {th }} 1955$, pov. br. 613/55.

${ }^{81}$ AJHM, p.b. 738, Dopis Irene Bence - SJVOJ-u.

${ }^{82}$ AJHM, p.b. 738, Dopis SJVOJ - JVO Zagreb, July $8^{\text {th }} 1955$, pov. br. 1464/55.

${ }^{83}$ AJHM, p.b. 738, Dopis Branka Poljaka - SJVOJ-u, February 22 $2^{\text {nd }}, 1954$, pov. br. 324/54. 


\section{REFERENCES}

- Alfassi, Itzhak. Immigration and Settlement. Jerusalem: Ketter Books, 1973.

- Crisp Richard, and Turner Rhiannon. Essential Social Psychology. London: Sage, 2007.

- Cvetković, Dragan. „Holokaust u Jugoslaviji - jedan pokušaj kvantifikacije“. In: Izraelsko-srpska naučna razmena u proučavanju Holokausta, Zbornik radova s naučnog skupa, Jerusalim-Jad Vašem, 15 - 20. jun 2006, 345-371. Beograd: Muzej žrtava genocida: 2008.

- Gahagan, Judy. Interpersonal and Group Behaviour. London: Methuen, 1975.

- Gruenfelder, Anna Maria. „Nepoželjni gosti. Židovske izbeglice u Jugoslaviji (1938-1945)“. Zbornik Jevrejskog istorijskog muzeja, br. 10, (2015), 303-362.

- Grünfelder, Anna. „Aufgeschobene Vernichtung. Jüdische Emigration nach Jugoslawien (1933-1938-1945)“. Südosteuropaforschung, nr. 71, (2012), 233-284.

- Ivanković, Mladenka. Brodovi nade. Alije jugoslovenskih Jevreja u Izrael. Beograd: Heraedu, 2017.

- Ivanković, Mladenka. Jevreji u Jugoslaviji (1944-1952), Kraj ili novi početak. Beograd: Institut za noviju istoriju Srbije, 2009.

- Ivanković, Mladenka. „Odlazak jevrejskih izbeglica - žrtava Holokausta iz evropskih zemalja za Palestinu preko teritorije Jugoslavije 1946/7. godine“. Tokovi istorije, br. 3, (2006), 141-153.

- Romano, Jaša. Jevreji Jugoslavije 1941-1945. Žrtve genocida i učesnici Narodnooslobodilačkog rata. Beograd: Savez jevrejskih opština, 1980.

- Koljanin, Milan. Jevreji i antisemitizam u Kraljevini Jugoslaviji 1918-1941. Beograd: Institut za savremenu istoriju, 2008.

- Neumann, Shoshanna. Aliyah to Israel: Immigration under Conditions of Adversity. Bonn: Forschungsinstitut zur Zukunft der Arbeit, 1999.

- Ovendale, Richie. Britain, the United States and the end of the Palestine mandate (1942-1948). London: Royal Historical Society, 1989.

- Radovanović, Milan. „Emigracija jevrejske dece iz Jugoslavije u Izrael (19481952) - Tri lične istorije“. Tokovi istorije, br. 2, (2017), 155-174. https://doi.org/10.31212/tokovi.2017.2.rad.155-174

- Radovanović, Milan. „Iseljenje jevrejske dece iz Jugoslavije u Izrael 1948/9”. Naša prošlost, br. 14, (2013), 161-170.

- Radovanović, Milan. „Der Transit jüdischer Migranten durch Jugoslawien nach Palästina und Israel (1933-1952) - der Fall Ernest Beschinsky“. Istorija 20. veka, br. 1, (2016), 109-118. https://doi.org/10.29362/ist20veka.2016.1.rad.109-118

- Radovanović, Milan. „Organizovana emigracija kapitala - „Zbirni račun repatriraca za Izrael“ (1948-1952)“. Arhiv, br. 1-2, (2017), 164-184.

- Radovanović, Milan. „Pojedini ekonomski aspekti organizovanog iseljavanja jugoslovenskih Jevreja u Izrael 1948/9. godine“. Godišnjak za društvenu istoriju, br. 3, (2011), 81-102. 
- Radovanović, Milan. „Pojedini statistički aspekti organizovanog iseljavanja Jevreja iz Jugoslavije u Izrael (1948-1952)“. Godišnjak za društvenu istoriju, br. 2, (2015), 53-81.

- Radovanović, Milan. „The State, the Organization and the Individual - A three-level Approach to Migration". In: Where is Civil Society in Central Europe heading to?. Edited by Inocent-Mária Staniszlo et al., 169-187. Prešov: Michal Vaško Press, 2015.

- Radovanović, Milan. „Cionizam i pragmatizam - Zašto su se jugoslovenski Jevreji iselili u Izrael? (1948-1952)“. Beogradski istorijski glasnik, br. 6, (2015), 215-249.

- Radovanović, Milan, „The internal Framework of Organized Jewish Migration from Yugoslavia to Israel (1948-1952)". Istorija 20. veka, br. 1, (2019), 130135. https://doi.org/10.29362/ist20veka.2019.1.rad.121-138

- Ristović, Milan. „Jugoslavija i jevrejske izbeglice 1938-1941“. Istorija 20. veka, br. 1, (1996), 21-43.

- Ristović, Milan. „Turisti pod sumnjom (o jednom vidu politike Kraljevine Jugoslavije prema jevrejskim izbeglicama 1938-1941. godine)“. U: Kladovo transport: Zbornik radova sa okruglog stola. Urednik Andrej Mitrović, 170189. Beograd: Jevrejski istorijski muzej, 2006.

- Ristović, Milan. U potrazi za utočištem - Jugoslovenski Jevreji u bekstvu od Holokausta. Beograd: Čigoja štampa, 2016.

- Ristović, Milan. „Unsere und fremde Juden. Zum Problem der Jüdischen Flüchtlinge in Jugoslawien 1938-1941“. In: Zwischen grossen Erwartungen und bösem Erwachen. Juden, Politik und Antisemitismus in Ost- und Südosteuropa 1918-1945. Herausgegeben von Dittmar Dahlmann und Anke Hilbrenner, 191-216. Paderborn - München: Schöningh, 2007. https://doi.org/10.30965/9783657757466_011

- Rot, Nikola. Psihologija grupa. Izabrana dela - tom IV. Beograd: Zavod za izdavanje udžbenika, 2010.

- Švob, Melita. Židovska populacija u Hrvatskoj i Zagrebu. Zagreb: Židovska općina Zagreb i Istraživački i dokumentacijski centar CENDO, 2010.

- Vajs, Albert. „Jevreji u novoj Jugoslaviji“. Jevrejski almanah, (1954), 5-47. 
MILAN RADOVANOVIĆ, PhD, Historian

Belgrade, Republic of Serbia

mradowanovic@gmail.com

\title{
MIGRATION SPAWNING MIGRATION - \\ ON CONTINUITY IN JEWISH EMIGRATION FROM YUGOSLAVIA TO PALESTINE/ISRAEL
}

\begin{abstract}
Summary
Yugoslav participation in Jewish emigration to Mandatory Palestine and, post 1948, to Israel, can be defined as a process consisting of six clearly separate stages. Each of these was defined by dramatic changes in internal and foreign political circumstances. The existence of clear borders between individual stages of migration can hardly be denied, if solely the socio-political context is examined. This discontinuity is however, hardly visible when the same process is brought down and analyzed on the level of participating families and individuals. The aspiration of an individual to join members of his families already in Palestine, especially after the tragic losses suffered by the community in the Holocaust, persevered as one of the key motives driving emigration from Yugoslavia. This paper deals with the way in which family ties continuously drove emigration to Mandatory Palestine/Israel and tied its individual stages into an integral whole. The relatively small community of Yugoslav Jews living in Mandate Palestine after World War Two had ended proved to be a driving force for further individual and then mass emigration. On account of the number of participants alone, organized emigration from Yugoslavia to Israel between 1948 and 1952 proved to be a particularly complex phenomenon. With every single wave of organized migration, the Yugoslav community in Israel became significantly more numerous and more influential in the sense of spawning further emigration. Apart from being influenced by previous stages of the migration process, organized emigration proved to be a self-sustaining movement, with every single wave influencing the waves to follow. This paper is primarily based on documents kept at the Archives of the Jewish historical Museum in Belgrade.
\end{abstract}

KEYWORDS: Migration, Yugoslavia, Israel, Jews, Continuity 